DOI 10.14746/ssp.2020.2.6

\title{
Michał SKORZYCKI
}

Społeczna Akademia Nauk

ORCID: 0000-0002-5519-2084

\section{Polityka europejska Słowacji w kontekście jej uczestnictwa w Grupie Wyszehradzkiej}

Streszczenie: Tekst podsumowuje główne cele i kierunki polityki europejskiej Słowacji, a także interesy państwa, które są realizowane w jej ramach. Artykuł zaczyna się od przeglądu najważniejszych interesów Republiki Słowackiej, bronionych poprzez prowadzenie polityki zagranicznej. Następnie przedstawione są uwarunkowania realizacji tego typu polityki oraz metody prowadzenia jednej z jej odnóg, tj. polityki europejskiej, po czym omówiony zostaje zakres wykorzystania własnej pozycji w UE w działaniach wewnątrz Grupy Wyszehradzkiej. Zasadniczym kontekstem analizy zawartej w tekście jest swoista sytuacja polityczna kraju, który jako jedyny należy zarówno do Grupy Wyszehradzkiej, jak i strefy euro. Jej głównym celem jest ukazanie sposobów i skali wykorzystania tej pozycji do realizacji własnych interesów. Słowacja pokazana jest jako państwo, którego polityka zagraniczna opiera się obecnie na silnych związkach z Niemcami i Francją, zapewniających mu dostęp do unijnych środków i zachodnich inwestycji oraz bezpieczeństwo energetyczne.

Słowa kluczowe: Słowacja, polityka zagraniczna, Grupa Wyszehradzka, Unia Europejska

D epublika Słowacka (RS) jest jedynym państwem Grupy WyszehRradzkiej (V4) należącym do strefy euro. Ta sytuacja daje jej szczególne położenie w Grupie, umożliwiające pełnienie roli pośrednika między krajami zrzeszonymi a największymi państwami członkowskimi UE i Komisją Europejską. W obliczu konfrontacyjnego kursu obserwowanego w polityce europejskiej Polski i Węgier, położenie Słowacji zapewnia jej szczególne możliwości w zakresie prowadzenia politycznej gry, służącej rekompensowaniu niskiego potencjału ludnościowego i gospodarczego za pomocą kapitału politycznego. Szansa ta dostrzeżona została już przez Niemcy, czego przejawem była choćby wypowiedź ministra spraw zagranicznych Sigmara Gabriela z sierpnia 2017 r., w której określił Słowację mianem pomostu między ,jądrem UE” a państwami członkowskimi z Europy Środkowo-Wschodniej. Celem niniejszego artykułu jest 
wyszczególnienie i scharakteryzowanie przypadków wykorzystywania wspomnianego usytuowania kraju - w kontekście zasadniczych kwestii spornych między V4 a Niemcami, Francją oraz Komisją Europejską - do realizacji jego interesów oraz poprawiania jego pozycji na arenie międzynarodowej.

Teoretyczną podstawą analizy był paradygmat racjonalistyczny w wersji klasycznej reprezentowanej przez Hansa Morgenthaua (Morgentau, 2010, s. 21, 27-29). Przyjęto zatem założenie, że polityka międzynarodowa opiera się na uniwersalnych i obiektywnych zasadach, z których główną jest dążenie aktorów do realizacji własnych interesów, które należy rozumieć w kategoriach siły. Kryterium oceny działań politycznych nie są zatem intencje prowadzących je podmiotów, ale ich efektywność w realizacji celów oraz racjonalność, połączona ze zdolnością do przedstawiania urzeczywistniania własnych aspiracji jako osiągania ogólnie akceptowanych celów o charakterze moralnym. Moralność należy przy tym rozumieć jako część kulturowego kontekstu działań, zaś przedkładanie indywidualnych „moralnych aspiracji” nad przetrwanie może prowadzić do skutków gorszych (w kategoriach etycznych) niż odstępstwa od wartości. Zdawać by się wprawdzie mogło, że do analizowania polityki państw należących do mocno zinstytucjonalizowanych ugrupowań integracyjnych i organizacji w rodzaju Unii Europejskiej bardziej nadawałyby się koncepcje republikańskiego czy instytucjonalnego liberalizmu, jednak pierwsza $\mathrm{z}$ nich wydaje się być fundamentem teoretycznym samej UE, zatem służyć może raczej do analizowania rozbieżności między teorią a praktyką, co nie mieści się w zakresie celów niniejszego tekstu. Druga z wymienionych, poprzez eksponowanie różnorodności powiązań wpływających na współzależność państw, gubi z kolei nieco sam sens polityki, która nadal jest prowadzona między państwami Unii, nawet jeśli zgodziły się one na dokonanie głębokiej integracji swoich gospodarek oraz zrezygnowały z przemocy jako formy rozwiązywania konfliktów i obrony własnych interesów wewnątrz ugrupowania. Nie doszło przy tym do stworzenia wspólnej europejskiej przestrzeni politycznej, a co za tym idzie państwo narodowe jest nadal zasadniczym fundamentem demosu i punktem odniesienia dla polityków zainteresowanych zdobyciem władzy. Pożyteczne stosowanie paradygmatu realistycznego nie wyklucza poszukiwania związków między polityką zagraniczną państwa a jego sytuacją wewnętrzną, czego dowodzi chociażby udany wywód Andrzeja Dybczyńskiego (Dybczyński, 2014, s. 70-71), w którym zwraca on uwagę na wewnętrzne uwarunkowania zawierania sojuszy międzypaństwo- 
wych, korzystając przy tym ze wspomnianej teorii. Uzupełnieniem teoretycznym w tym aspekcie była socjologiczna teoria racjonalnego wyboru, tłumacząca zależności między racjonalnym postępowaniem aktorów dążących do maksymalizacji korzyści, a racjonalnością kolektywnych skutków ich działań (Hechter, Kanazawa 2006, s. 165).

Realizacja celu niniejszej pracy zaczyna się od wyodrębnienia obecnych priorytetów polityki zagranicznej Republiki Słowackiej oraz interesów chronionych poprzez jej prowadzenie. Następnie zarysowywane zostają podstawowe uwarunkowania wewnętrzne polityki zagranicznej Słowacji oraz zasadnicze sposoby realizacji interesów Słowacji poprzez prowadzenie polityki europejskiej i udział w Grupie Wyszehradzkiej. Analizie poddano wybrane posunięcia rządu i prezydenta RS, zaobserwowane w latach 2010-2019, chociaż dla ich pełnego zrozumienia konieczne było niejednokrotnie zarysowywanie kontekstu historycznego poprzez odwoływanie się do wcześniejszych wydarzeń. Kryteriami wyboru działań politycznych poddanych analizie były: ich treściowa spójność z kierunkiem polityki europejskiej, logiczny związek z realizowaniem celów i interesów Słowacji wymienionych w cytowanym dokumencie strategicznym polityki zagranicznej RS (Úspešné) oraz związki z polityką prowadzoną w stosunku do pozostałych państw Grupy Wyszehradzkiej.

\section{Zasadnicze interesy Republiki Słowackiej realizowane poprzez prowadzenie polityki zagranicznej}

Priorytety polityki zagranicznej Słowacji opisane w strategii mającej stanowić jej podstawę, przyjętej przez rząd w Bratysławie, są typowe dla niewielkiego państwa, obrazując jego tendencję do multilateralizmu ułatwiającego mu zmaganie się z konkurencją większych krajów i zapewnienie sobie dogodnej pozycji negocjacyjnej. Widać to choćby przy okazji kwestii obronności, która nie jest wyrażona wprost, a za pośrednictwem priorytetu "Wzmocnienie bezpieczeństwa obszaru euroatlantyckiego" (Úspešné, s. 7). Jeden z sześciu priorytetów zatytułowany „Interesy RS w efektywnej UE" dosyć bezpośrednio określa podstawowe założenia polityki europejskiej Słowacji, sformułowane za pośrednictwem trzech celów strategicznych:

- wzmocnienie promocji interesów Republiki Słowackiej w UE i jej wpływu na tworzenie wspólnych polityk UE; 
- promowanie rozszerzenia UE w oparciu o ścisłe przestrzeganie kryteriów przedakcesyjnych;

- przyczynianie się do wzmocnienia skutecznego funkcjonowania instytucji UE (Úspešné, s. 4).

W ramach pierwszego $\mathrm{z}$ nich, poziomem precyzji wyróżnia się dążenie do ,zakończenia tworzenia jednolitego rynku wewnętrznego UE i stopniowego usuwania barier z europejskiego rynku pracy, usług i energii”, mogącego poprawić stan bezpieczeństwa energetycznego kraju oraz dodatkowo zwiększyć jego atrakcyjność inwestycyjną. W ramach tego priorytetu Słowacja ma także dążyć do ,[...] zastosowania traktatu lizbońskiego i wykorzystania nowych ram instytucjonalnych UE do egzekwowania interesów Republiki [...]”.

Poza tym RS wspiera poszerzenie ugrupowania o państwa Zachodnich Bałkanów oraz Turcję, dążąc do „[...] pogłębienia współpracy, procesu integracji i konsolidacji UE" (Úspešné, s. 4). Jednocześnie w ramach realizacji priorytetu związanego w rozwojem gospodarczym, słowacka polityka zagraniczna zmierza w kierunku zwiększenia bezpieczeństwa energetycznego, zaś wśród celów strategicznych związanych z bezpieczeństwem i demokratyzacją znalazła się ,regulacja imigracji zgodnie zinteresami RS".

$\mathrm{Z}$ treści dokumentu programowego wyłaniają się zatem cztery główne interesy państwa, których obronie ma służyć jego polityka zagraniczna:

- zwiększanie poziomu bezpieczeństwa militarnego i energetycznego;

- zwiększanie poziomu eksportu i inwestycji;

- utrzymanie transferów finansowych przekazywanych przez unijne Fundusze oraz w ramach WPR;

- zapewnianie państwu wpływów politycznych w UE.

\section{Podstawowe uwarunkowania wewnętrzne polityki zagranicznej Slowacji}

Politykę zagraniczną Słowacji prowadzi rząd, odpowiedzialny przed Radą Narodową Republiki Słowackiej i powoływany (wraz z przewodniczącym) przez Prezydenta Republiki Słowackiej (Konstytucja, art. 110,111, 114 ust. 1, 119 p. i.). Konstytucja nie przewiduje liczby, nazw czy konkretnych uprawnień poszczególnych ministerstw, powierzając ich powoływanie Radzie Narodowej, wykonującej swoje prerogatywy w tym względzie na drodze ustawowej (Ústava). Realizacją polityki za- 
granicznej zajmuje się obecnie Ministerstwo Spraw Zagranicznych i Europejskich Republiki Słowackiej, powołane do życia ustawą z 2016 r. (Štatút).

Pewne uprawnienia jej dotyczące posiada także prezydent wybierany w wyborach powszechnych na pięcioletnią kadencję, do którego kompetencji należy reprezentowanie Republiki Słowackiej na zewnątrz (Konstytucja, art. 101 ust. 2, ust. 1) oraz zawieranie i ratyfikowanie umów międzynarodowych, przy czym zawieranie umów może delegować na rząd lub, za jego zgodą, na jego poszczególnych członków, dysponując jednocześnie uprawnieniem do żądania ,[...] od rządu Republiki Słowackiej oraz od jego członków informacji niezbędnych do wykonywania swoich kompetencji” (Konstytucja, art. 102, ust. 1. p. a, r.). Część umów międzynarodowych musi być też zatwierdzana przez Radę Narodową (Konstytucja, art. 86, p. e.).

Słowacja jest krajem małym, nieposiadającym głębi strategicznej ani większego potencjału demograficznego i militarnego, a zatem w dziedzinie obronności jest zdana na sojusze. Siły zbrojne tego państwa zatrudniają przy tym tylko 18 tys. żołnierzy i oficerów, zaś armia cierpi na niedoinwestowanie objawiające się niskimi płacami kadry i takąż obecnością nowoczesnego sprzętu (Łada, 2017, s. 9). Sytuacja ta jest spowodowana faktem, że wysokość wydatków na obronność wynosi jedynie $1,16 \%$ PKB - spadła z wymiaru 1,7\% utrzymywanego przed wejściem do NATO - (Goda, Goszkowski, 2016, s. 59), acz przed warszawskim szczytem NATO w lipcu 2017 r. rząd zapowiedział podniesienie tego odsetka do 1,6\%, zaś docelowo do 2\% w 2024 r. (Goda, Goszkowski, 2016, s. 59; Słowacja: F-16, 2018). Rozpoczęto też program modernizacji armii, w ramach którego podjęto decyzję o zakupie 9 śmigłowców Black Hawk, dwóch samolotów transportowych C-27J Spartan oraz 81 kołowych transporterów opancerzonych Patria AMV, zapowiadając też nabycie 41 pojazdów opancerzonych i wymianę radzieckich samolotów MiG-29, prawdopodobnie na F-16V Block 70/72 lub Jas-39E/F Gripen NG (Stowacja: F-16, 2018).

Populacja państwa w 2018 r. wynosiła 5432 tys. osób, zaś terytorium - 49035 tys. $\mathrm{km}^{2}$ (Warunki życia; Słowacja liczba ludności). Słowacja jest przy tym jedynym państwem V4 graniczącym z wszystkimi pozostałymi, a jej granice z partnerami z Grupy są dłuższe od pozostałych - 679 km z Węgrami, 597,5 km z Polską, 265 km z Czechami. Poza tym graniczy z Austrią $(127,2 \mathrm{~km})$ i ze strefą poradziecką za pośrednictwem Ukrainy - 98 km (Warunki życia). Konsekwencją położenia jest zaintere- 
sowanie regionalnymi związkami wewnątrz UE oraz czerpaniem zysków z tranzytu rosyjskich węglowodorów przesyłanych do Europy, zapewniającego budżetowi wpływy w wysokości około $150 \mathrm{mln}$ euro rocznie (Dąborowski, Groszkowski, 2015) ${ }^{1}$.

Istotnym czynnikiem wpływającym na politykę zagraniczną Słowacji jest otwarty charakter jej gospodarki opartej na eksporcie i inwestycjach zagranicznych ${ }^{2}$, będący skutkiem reform gabinetów Mikulasza Dzurindy, opartych na założeniach neoliberalizmu oraz neoinstytucjonalizmu (Ručinská, 2010, s. 162). Władze zdecydowały o wykorzystaniu taniej siły roboczej oraz niskiego opodatkowania do przyciągnięcia inwestycji, skutkiem czego drugi rząd Dzurindy nie zgodził się na harmonizację podatków pośrednich i polityki socjalnej z innymi państwami UE (Bilčík, Groszkowski, 2016, s. 31). Dominującym produktem eksportowym stały się wyroby przemysłu motoryzacyjnego, zlokalizowanego w zachodniej - zakłady Volkswagena w Bratysławie oraz PSA w Tarnawie, a także uruchamiana obecnie fabryka firmy Jaguar/Land Rover w Nitrze (Kublik 2018) - centralnej i północnej (fabryka KIA Motors w Žilinie) oraz wschodniej części kraju - w rejonie miast Koszyce i Kochenec, gdzie produkuje się układy napędowe w zakładach Ford Gertrag i Molex (Lizak, 2011, s. 146-147).

Dążenie do dalszego wzrostu inwestycji było bodźcem do zamiany autonomicznej waluty na euro, dobrze przyjęte przez dotychczasowych inwestorów ze względu na obniżenie kosztów bankowych i administracyjnych oraz ryzyka kursowego i stanowiące jednocześnie dla nowych dowód na stabilność słowackiej gospodarki, zdolnej do spełnienia (niemałym kosztem społecznym) restrykcyjnych warunków przyjęcia do strefy euro (Slovakia and the European Union, 2010, s. 195).

Sytuacja ta skłania słowackich decydentów do utrzymywania kraju w głównym nurcie integracyjnym, przy czym wykazują oni ograniczoną aktywność w zakresie proponowania własnych rozwiązań wspólno-

1 Słowacja ma jedną z najbardziej zagęszczonych sieci przesyłowych gazu w UE, będąc najistotniejszym państwem tranzytowym tego paliwa w Europie Środkowej, przez którego terytorium rocznie transportowanych jest około $95 \mathrm{mld} \mathrm{m}^{3}$ gazu, którego większa część trafia do odbiorców w Czechach, Niemczech, Austrii, Francji, Włoszech, Węgrzech, Słowenii i Chorwacji (Pronińska, 2013, s. 25). Zapotrzebowanie krajowe na surowiec sięga jedynie $5 \mathrm{mld} \mathrm{m}^{3}$ (Dąborowski, Groszkowski, 2015).

2 Już dwa lata po wejściu do UE obroty Słowacji w handlu zagranicznym sięgnęły $160 \%$ PKB, a przy tym $80 \%$ z nich było realizowane w euro (Nič, Slobodník, Šimečka, 2014, s. 7). 
towych. Może to być spowodowane słabo rozwiniętym zapleczem eksperckim oraz brakiem właściwej akademickiej dyskusji nad kwestiami reform instytucjonalnych UE. W związku z tym dosyć ograniczone są możliwości monitorowania działań kolejnych ekip rządzących, a co za tym idzie brak jest presji oraz zaplecza doradczego, które spowodowałaby formułowanie śmiałych programów w zakresie polityki europejskiej (Nič, Slobodník, Šimečka, 2014, s. 10).

Poza tym obecność kwestii europejskiej w dyskusji publicznej jest niewielka, z którego to względu sprawy mieszczące się w jej zakresie są zazwyczaj przedmiotem uzgodnień elit politycznych, biznesowych i administracyjnych (Nič, Slobodník, Šimečka 2014, s. 7). Jeżeli już tematyka unijna pojawia się w publicznej przestrzeni, jest zazwyczaj ograniczona do spraw związanych z dystrybucją środków, w rodzaju wykorzystania funduszy strukturalnych, czy kwestii wsparcia dla niestabilnych finansowo państw strefy euro (Bilčík, s. 2).

Sytuacja ta ma wyraźne źródła społeczne, określone przez Vladimíra Bilčíka mianem „słowackiego paradoksu” (Bilčík, s. 2). Polega on na połączeniu wysokiego poparcia dla pozostawania Słowacji w UE oraz głównym nurcie integracyjnym z powszechnym brakiem zainteresowania wobec unijnej polityki. Jaskrawym przykładem tego fenomenu było połączenie najniższej (trzeci raz z rzędu) w Unii frekwencji w wyborach do Parlamentu Europejskiego w 2014 roku (13\%) z (kontrastującym z wieloma innymi krajami) wykazywanym przez słowackich wyborców brakiem poparcia dla partii eurosceptycznych w wyborach do PE oraz wysokim odsetkiem osób dobrze oceniających wówczas obecność kraju w UE i strefie euro - wynik ustępował jedynie rezultatom analogicznych badań przeprowadzonych w Niemczech i w Polsce (Bilčík, s. 2; Nič, Slobodník, Šimečka, 2014, s. 10). Co więcej, badania przeprowadzone tuż przed wyborami w ramach programu Eurobarometr wykazały, że tylko w pięciu państwach członkowskich respondenci deklarują (nieznacznie) wyższe zaufanie do PE niż Słowacy; sięga ono wśród nich 56\% (Standardowy Eurobarometr 80, 2013, s. 3).

Zarysowane wyżej zjawisko społeczne wskazuje na sytuację panowania w społeczeństwie słowackim nieprzepracowanego euroentuzjazmu, który w obecnej sytuacji pozwala elitom na utrzymanie proeuropejskiego kursu, ale jest podstawą dosyć niestabilną, która może nie wytrzymać prób zmiany relacji wpływów i wpłat do budżetu oraz konieczności dokonywania poświęceń na rzecz wspólnych interesów UE. Bratysława zademonstrowała już ten wariant zachowania, decydując się na zaskar- 
żenie do TSUE decyzji Rady z września 2015 r. dotyczącej obowiązku przyjmowania kwot uchodźców przez państwa członkowskie, mimo wątpliwych podstaw prawnych, skutkujących oddaleniem skargi (Słowacja: szanujemy, 2017). Wcześniej, 11 października 2011 roku, słowacki parlament odrzucił projekt reformy Europejskiego Instrumentu Stabilności Finansowej, zakładający wsparcie dla członków strefy euro zagrożonych bankructwem. Finalnie projekt został przyjęty dwa dni później dzięki poparciu ówczesnej opozycji, jednak akceptacja partycypacji RS w ,pakiecie ratunkowym" (udział państwa w finansowaniu pożyczki dla Grecji miał wynieść 816 mln euro) spowodowała upadek centro-prawicowego rządu koalicyjnego Ivety Radičovej, wcześniej przyczyniając się do porażki wyborczej pro-unijnej Partii Smer-Socjalna Demokracja i ukazując brak społecznej akceptacji dla obciążeń solidarnościowych wynikających z członkostwa w strefie (Groszkowski, 2011; Mesík, 2010).

Na tym tle możliwa jest popularyzacja interpretacji integracji europejskiej jako projektu elit, której sprzyjają przypadki nielegalnego czerpania ze środków unijnych przez nieformalne grupy biznesmenów i polityków, ujawniane przykładowo w czasie realizacji projektu budowy autostrad oraz - w sposób bardziej spektakularny - w sprawie zabójstwa dziennikarza śledczego Jána Kuciaka, badającego przykłady nielegalnej eksploatacji wspomnianych funduszy przez kalabryjskie zorganizowane grupy przestępcze, korzystające $\mathrm{z}$ kontaktów w kręgach rządowych (Kuciak, 2018). Afera doprowadziła do fali demonstracji, pod naporem których doszło do rekonstrukcji gabinetu, obejmującej ustąpienie premiera Roberta Fico oraz ministra spraw wewnętrznych Roberta Kaliniaka (Meredith, 2018). Wspomnianej interpretacji sprzyjać może panujący w kraju poziom zaufania do instytucji, należący do najniższych w UE. W pierwszej połowie 2018 r. 77\% słowackich respondentów Eurobarometru wyraziło nieufność wobec rządu, 72\% - wobec parlamentu, 82\% - wobec partii politycznych a $72 \%$ - wobec wymiaru sprawiedliwości (Standard Eurobarometer 89, 2018, s. 42-44, 48). Istnieje zatem w społeczeństwie słowackim znaczny potencjał niezgody na dalsze pogłębianie integracji z UE, który może w przyszłości poważnie skomplikować prowadzenie polityki europejskiej przez władze.

Należy też zwrócić uwagę na zwiększenie eurosceptycyzmu słowackich parlamentarzystów. Po wyborach z 2016 r. Smer wprawdzie utrzymał się przy władzy, ale zanotował spadek popularności, redukujący liczbę jego posłów z 83 do 49 (Slovakia). Trzeba zresztą zwrócić uwagę, że w początkowej fazie swojej działalności partia ta krytykowała rządzącą 
wtedy prawicę za zbytnią uległość, przejawianą rzekomo w trakcie negocjacji akcesyjnych, zaś jej członkowie zaczęli przejawiać wyraźnie poglądy prointegracyjne dopiero po decyzji przewodniczącego Ficy o przyjęciu ideologii socjaldemokratycznej po wyborach z 2002 r. (Bajda, Zenderowski, 2017, s. 26). Co więcej, cztery lata później Smer wszedł w koalicję rządową z opóźniającym integrację Ruchem na Rzecz Demokratycznej Słowacji (HZDS) Vladimíra Mečiara oraz z nacjonal-populistyczną i prorosyjską Słowacką Partią Narodową (SNS), gromadzącą kapitał polityczny dzięki epatowaniu wyborców negatywnym stosunkiem do mniejszości narodowych.

Słabszy wynik zanotowało też liberalne i prounijne ugrupowanie Most-Hid, jednoczące działaczy pochodzenia słowackiego i węgierskiego, tracąc 2 z 13 posłów. Poza tym wyborczego progu nie udało się przekroczyć, przychylnemu integracji, konserwatywnemu Ruchowi Chrześcijańsko-Demokratycznemu $(\mathrm{KDH})$ oraz założonej przez Dzurindę Słowackiej Unii Chrześcijańsko-Demokratycznej-Partii Demokratycznej (SDKU-DS), która odegrała kluczową rolę przy wprowadzaniu Słowacji do UE (Slovakia). Do Rady Narodowej wrócili natomiast po czteroletniej przerwie reprezentanci SNS (15 posłów), zaś po raz pierwszy zasiedli w niej przedstawiciele nacjonalistycznej Partii Narodowej Nasza Słowacja (L'SNS), kierowanej przez byłego marszałka województwa bańsko-bystrzyckiego Mariana Kotlebę, który domaga się opuszczenia NATO i UE, prowadząc akcję zbierania podpisów pod wnioskiem o ogłoszenie referendum w tej sprawie (Bajda, Zenderowski, 2017, s. 31).

Poza tym znaczny wzrost poparcia (z 11 do 21 posłów) zanotowała umiarkowanie eurosceptyczna Partia Wolność i Solidarność (SaS), sprzeciwiająca się przyjęciu traktatu z Lizbony i domagająca się wprowadzenia obowiązku akceptowania każdej propozycji przekazywania przez Słowację kompetencji Komisji Europejskiej poprzez głosowanie w Radzie Narodowej kwalifikowaną większością 3/5 głosów (Bajda, Zenderowski, 2017, s. 27-28). Z 16 do 19 posłów powiększyło też reprezentację parlamentarną ostrożnie eurosceptyczne stronnictwo Zwykli Ludzie i Niezależne Osobowości (OL'aNO-NOVA), które wraz z SaS umieściło swoich europarlamentarzystów we frakcji Konserwatystów i Reformatorów. Trudny do określenia stosunek do kwestii związanych z integracją ma zaś nowe, założone przez milionera Borisa Kollára, ugrupowanie Jesteśmy Rodziną, które po raz pierwszy uzyskało reprezentację parlamentarną (Bajda, Zenderowski, 2017, s. 28). Wyraźniejsze stanowisko zaprezentował natomiast zrzeszający różne inicjatywy obywatelskie ruch 
Siet', którego kierownictwo poparło zbliżenie Słowacji do jądra integracji gospodarczej UE (Bajda, Zenderowski, 2017, s. 28).

\section{Metody realizacji interesów RS przy pomocy polityki europejskiej}

Zapewnienie państwu bezpieczeństwa w sensie militarnym i energetycznym jest realizowane przez RS na kilku płaszczyznach polityki europejskiej.

Pierwsza z nich ma charakter ekonomiczny. Wspomniana otwartość słowackiej gospodarki ma podnieść koszty, które poniosłaby gospodarka europejska po zajęciu Słowacji przez mocarstwo trzecie. W tym sensie bezpośrednie inwestycje zagraniczne stanowią substytut surowców naturalnych bądź dużego rynku zbytu, wiążąc interesy silniejszych państw (szczególnie Niemiec) z suwerennością RS.

Druga płaszczyzna ma już charakter stricte militarny. Jak zostało wspomniane, własny potencjał wojskowy kraju jest niewystarczający do prowadzenia samodzielnej obrony. Jej podstawą musi być zatem system sojuszy, z których kluczowe znaczenie ma oczywiście NATO. Warto jednak zwrócić uwagę, że poziom zaangażowania w sojusz ze Stanami Zjednoczonymi, kryjący się pod uczestnictwem w organizacji, nie jest traktowany tak ostentacyjnie, jak w przypadku Polski, ze względu na mniejszy entuzjazm elit i opinii publicznej wobec polityki amerykańskiej oraz ich bardziej pozytywny stosunek do Rosji. RS nie kontynuuje jednak polityki premiera Mečiara, który rozważał ogłoszenie Słowacji państwem neutralnym w zamian za tanie rosyjskie surowce i wsparcie dyplomatyczne (Bajda, 2010, s. 262).

Aż do kryzysu gazowego z 2009 roku kolejne słowackie rządy nie podejmowały wysiłków na rzecz dywersyfikacji dostaw węglowodorów, skutkiem czego RS do dzisiaj należy do grupy państw o jednym z najwyższych stopni uzależnienia energetycznego od Rosji. Z tego względu Słowacja niechętnie odnosi się do prób stosowania przez UE bardziej zdecydowanej polityki wobec Kremla, czego dobitnym przejawem był sprzeciw premiera Ficy wobec zamierzeń wprowadzenia poważniejszych wspólnotowych sankcji gospodarczych po zajęciu przez Rosję Krymu i zgłoszenie désintéressement wobec jej konfliktu z Ukrainą, wzmocnione stwierdzeniem, że to Ukraina odpowiada za zaistniałą sytuację. Stanowisko to potwierdzane zostało gestem w postaci wizyty w Moskwie Miroslava Lajčáka, ministra spraw zagranicznych i zarazem absolwenta 
moskiewskiej MGIMO, w czasie gdy przedstawiciele innych państw UE odwoływali zapowiedziane przyjazdy (Palata, 2014).

Ten sam premier Fico zasłynął też z krytyki Stanów Zjednoczonych, uzupełnionej o przedterminowe wycofanie słowackiego kontyngentu z Iraku. Poparcie słowackiej opinii publicznej dla pozostawania kraju w NATO jest przy tym wyraźnie niższe niż akceptacja członkostwa w UE (58,2\% do $73,9 \%)$, co sprawia że przejazdy kolumn wojsk państw sojuszu nie spotykają się z entuzjazmem, a fakt prowadzenia przez nie ćwiczeń na jednym ze słowackich poligonów nie jest nagłaśniany (Prieskum, 2017; Łada, 2017, s. 9). Ponadto trzeba tu przypomnieć, że w Radzie Narodowej zasiadają przedstawiciele dwóch partii domagających się wystąpienia z organizacji. Ta sytuacja zwiększa gotowość RS do uczestniczenia w dodatkowych projektach związanych z obronnością. Stąd udział kraju w stałej współpracy strukturalnej w dziedzinie obrony (PESCO) - unijnej inicjatywie, z której słowacki rząd chce skorzystać m.in. w celu optymalizacji swoich programów zbrojeniowych oraz uzyskania dla nich dodatkowego finansowania (Slovakia joins).

W ostatnich latach Słowacja wzmogła jednak przede wszystkim intensywność wykorzystywania polityki europejskiej w celu zapewniania sobie bezpieczeństwa energetycznego. Wspomniane już dobre relacje z Rosją nie są bowiem w stanie dostatecznie go zagwarantować ze względu na pośrednictwo Ukrainy i poziom napięcia w stosunkach Moskwa-Kijów. Dowiodło tego odcięcie dostaw gazu ziemnego wywołane konfliktem tych państw na początku 2009 r., które wywołało konieczność wstrzymania produkcji w wielu słowackich fabrykach, doprowadzając do strat o wartości przekraczającej miliard dolarów i spowolnienia wzrostu gospodarczego o około 1-1,5\% PKB (Palata, 2014; Dąborowski, Duleba, 2016, s. 72).

Warto tutaj nadmienić, że RS wykazuje największe uzależnienie importowe w zakresie surowców energetycznych spośród wszystkich państw V4 (Pronińska, 2013, s. 12). Nadrabia to jednak w pewnym stopniu przy pomocy najbardziej zróżnicowanego ze wszystkich krajów Grupy bilansu energetycznego, podnoszącego nieco odporność kraju na wstrzymanie dostaw rosyjskich (Pronińska, 2013, s. 11). W tej sytuacji w interesie Słowacji leży dywersyfikacja źródeł dostaw gazu ziemnego, co nie musi jednak oznaczać dążenia do zdecydowanego zwiększenia liczby państw dostarczających surowiec, a jedynie do zapewniania krajowi możliwości w zakresie importu z pominięciem Ukrainy. Drogą do osiągnięcia tego zamierzenia jest współpraca z państwami regionu w formule V4 oraz 
V4+, dająca Słowacji potencjalną solidarność sąsiadów w razie kolejnego kryzysu gazowego oraz szansę na rozbudowę połączeń o zdolności rewersyjnej, zapewniających państwu alternatywną drogę przesyłową. Wpisane we współpracę wyszehradzką dążenie do utworzenia wspólnego rynku gazowego, celem poprawienia pozycji negocjacyjnej, jest dla RS raczej kosztem niż zyskiem, ze względu na to, że już teraz udaje jej się uzyskiwać niskie ceny surowca od rosyjskiego dostawcy, a solidarność ze skłóconą z Moskwą Polską może spowodować ich wzrost.

Aby zwiększyć swoje bezpieczeństwo energetyczne, Słowacja wzięła udział w inicjatywie korytarza energetycznego północ-południe, która znalazła się wśród tematów budapesztańskiego szczytu energetycznego państw V4+ z 2010 r. i została uzupełniona wspólną deklaracją ministrów ds. energii krajów V4 wydaną rok później, zakładającą stworzenie połączeń infrastrukturalnych, które zapewnią zrzeszonym państwom dostęp do dwóch źródeł gazu spoza UE (Pronińska, 2013, s. 64-65). Stanowi ona też zajęcie dla powołanej w 2009 r. grupy roboczej ds. infrastruktury, przemianowanej następnie na grupę wysokiego szczebla ds. bezpieczeństwa energetycznego (Dąborowski, Duleba, 2016, s. 73). W ramach tych działań planowany jest interkonektor łączący Polskę ze Słowacją, budowany przez Gaz-System i Eustream a.s., na który przeznaczono niemal jedną czwartą środków będących do rozdysponowania w ramach unijnego programu „Łącząc Europę” - 107,741 mln euro (Szafrańska, 2017). Ma on połączyć miejscowość Strachocina w województwie podkarpackim ze stacją kompresorową Vel'ké Kapušany, osiągając przepustowość 4,7 mld $\mathrm{m}^{3}$ rocznie w kierunku Słowacji oraz od 4,3 do 5,7 $\mathrm{mld} \mathrm{m}^{3}$ w przeciwnym. Rozpoczęcie budowy jednak opóźnia się, prawdopodobnie $\mathrm{z}$ tego samego powodu, dla którego nie oddano jeszcze łącznika polsko-czeskiego. Strona polska jako priorytetową uważa budowę gazociągu Baltic Pipe dla pozyskiwania surowca norweskiego, chcąc zapobiec sytuacji tłoczenia do kraju gazu z linii przesyłowej Nord Stream II, jeśli zostałaby oddana do użytku wcześniej. Prognozowany termin ukończenia polsko-słowackiego łącznika został przesunięty z roku 2019 na 2020.

RS wykorzystuje również politykę europejską do zahamowania wspomnianej inicjatywy rosyjsko-niemieckiej, która zagraża jej pozycji jako kraju przesyłowego. Z tego względu delegacja słowacka odniosła się krytycznie do tej koncepcji na szczycie państw NATO z 2017 r. Wyraziła nawet aprobatę dla mocnych słów prezydenta Donalda Trumpa, którego zdaniem gazociąg czyni z Niemiec ,zakładnika” Rosji. Prezydent Andrej Kiska i sekretarz stanu w Ministerstwie Spraw Zagranicznych i Europej- 
skich Ivan Korčok, podważali jednak sens budowy drugiej nitki Gazociągu Północnego, używając argumentów bardziej uniwersalnych niż zagrożenie dla dochodów RS związanych z opłatami przesyłowymi, wskazując na to, że projekt zwiększa uzależnienie UE od Rosji i jednocześnie ma ograniczony sens ekonomiczny w obliczu niepełnego wykorzystania pierwszej nitki rurociągu (Slovakia supports, 2017).

Słowackie władze zrobiły jednak niewiele w kierunku zatrzymania projektu, posługując się Polską jako „lodołamaczem”. Z punktu widzenia małego kraju jest to rozwiązanie racjonalne, bowiem zmierza do załatwienia sprawy bez strat politycznych, które wiązałyby się z konfliktem z Niemcami i Rosją. Reakcja na realizację koncepcji Gazociągu Północnego, której pierwszy etap - czyli oddanie do użytku gazociągu Nord Stream I - spowodował spadek przepływu gazu przez Słowację o 37\% w latach 2011-2014, ma raczej charakter dostosowawczy (Dąborowski, Groszkowski, 2015). RS dąży nie tyle do radykalnego ograniczenia eksportu z Rosji, co do utrzymania statusu kraju tranzytowego oraz zapewnienia ciągłości dostaw surowca. $Z$ tego względu podjęła działania, które mieszczą się w jej polityce europejskiej. W krótkiej perspektywie skorzystała z nowo utworzonego „trójkąta sławkowskiego”, proponując (w maju 2015 r.) jego pozostałym uczestnikom integrację rynków gazu poprzez powiększenie przepustowości, usytuowanego przy przecięciu granic trzech państw, punktu Lanžhot z 24,5 do 51 mld $\mathrm{m}^{3}$ rocznie oraz uruchomienie ,wirtualnego gazociągu” przez Słowację łączącego systemy przesyłowe Czech z austriackim hubem w Baumgarten. Słowacki Eustream zaproponował przy tym wykorzystanie mechanizmu sprzężenia rynków, czyli łączenia aukcji z rezerwacją przepustowości, znanego $z$ handlu energią elektryczną. Trzeba zaznaczyć, że propozycja ta jest bardziej ostrożna, niż wcześniejsza inicjatywa utworzenia z tych państw tzw. „regionu gazowego”, z której RS wystąpiła w 2013 r. nie chcąc, jak przypuszczają Dąborowski i Groszkowski, tracić dochodów z opłat przesyłowych (Dąborowski, Groszkowski, 2015). W dalszej perspektywie Słowacja planuje powiększać możliwości przesyłowe z Węgrami i Polską, łącząc je przy tym z tureckim kierunkiem pozyskiwania surowca poprzez planowany gazociąg Eastring, biegnący przez Bułgarię, Rumunię i Węgry, którym ma być tłoczony gaz wydobywany pod Morzem Kaspijskim, na Bliskim Wschodzie oraz (w przyszłości) na szelfie Morza Czarnego należącym do Rumunii (At a glance). Użyteczna więc będzie tutaj inicjatywa $\mathrm{V} 4+$, zwłaszcza w kontekście pozyskania finansów na pokrycie kosztów inwestycji ze źródeł unijnych. 
Zwiększanie poziomu eksportu i inwestycji również wspomagane jest przez politykę europejską RS. Wykracza ona jednak poza tradycyjne formy korzystania z placówek dyplomatycznych celem przyciągania inwestorów, zadeklarowane w rządowej strategii polityki zagranicznej (Úspešné, s. 8). Instrumentami służącym temu celowi, należącymi do kategorii polityki europejskiej, jest utrzymywanie dobrych stosunków z Francją i z Niemcami, czyli głównymi źródłami inwestycji, zwłaszcza $\mathrm{w}$ przemyśle motoryzacyjnym, oraz wzmacnianie integracji UE w dziedzinie gospodarczej, czego wyrazem było zadeklarowane w programie słowackiej prezydencji z drugiej połowy 2016 r. utworzenie jednolitego rynku usług cyfrowych.

Trudno ocenić, który z tych celów będzie priorytetowy w wypadku niemożliwości ich pogodzenia. Decyzje w tej materii są zazwyczaj podejmowane ad hoc i zależą od doraźnych pragmatycznych kalkulacji. Przykładem tego była głośna sprawa zaproponowanej przez Francję nowelizacji dyrektywy 96/71/WE Parlamentu Europejskiego i Rady z dnia 16 grudnia 1996 r. dotyczącej delegowania pracowników w ramach świadczenia usług, która wymagałaby od pracodawców wysyłających osoby zatrudnione za granicę opłacania ich według miejscowych stawek. Zdawało się, że w tej sytuacji rząd zdecyduje się na wsparcie, korzystnej dla słowackiej gospodarki, reguły wolnej konkurencji, pozwalającej RS na uzyskiwanie przewagi w konfrontacji z silniejszymi państwami, na co wskazywało podpisanie przez premiera Ficę wspólnej deklaracji szefów państw V4 w maju 2017. Wyrażono w niej sprzeciw wobec koncepcji francuskiej, domagając się wyłączenia usług transportowych z zakresu definicji delegowania (Joint Statement, 2017). Stanowisko to, korzystne dla Polski, której firmy delegowały w tym czasie około pół miliona pracowników do innych krajów UE, słowacki premier powtórzył ponownie w czasie rozmowy telefonicznej z premier Beatą Szydło pod koniec sierpnia tego samego roku (Czeski minister, 2017), niedługo wcześniej akceptując propozycje francuskie na spotkaniu premierów państw „,trójkąta sławkowskiego" z prezydentem Emmanuelem Macronem w Linzu (Rozwadowska, 2017). W październiku 2017 r. reprezentacja RS zagłosowała za nowelizacją dyrektywy w trakcie posiedzenia Rady.

Działania na rzecz utrzymania dobrych relacji z europejskimi mocarstwami regionalnymi są jednak szczególnie wyraźne w odniesieniu do Niemiec. Państwo to jest głównym partnerem handlowym Słowacji (Bajda, Zenderowski, 2017, s. 5.), a zarazem najistotniejszym partnerem politycznym, z którym sojusz jest o tyle łatwy, że niska liczba utrwalonych 
społecznie zbiorowych wspomnień o dwustronnych konfliktach nie stwarza dogodnych warunków społecznych do szukania przez partie kapitału politycznego $\mathrm{w}$ przekonywaniu opinii publicznej o rzekomych niebezpieczeństwach związanych z niemieckim prymatem w Europie. Słowacy zazwyczaj przyjmują stanowisko niemieckie w sprawach kluczowych dla UE, jak to było w przypadku metod wyprowadzania strefy euro z kryzysu. RS poparła kurs oszczędnościowy, widząc jednocześnie w dalszej integracji prowadzonej wokół strefy euro sposób na pokonanie kłopotów UE. Wyraził to dobitnie premier Fico w swoim expose z 2016 r., wskazując na Niemcy jako głównego (poza Republiką Czeską) partnera strategicznego, jak również wyrażając poparcie wobec projektu integracji fiskalnej (Bajda, Zenderowski, 2017, s. 26). Stolice kluczowych państw UE nie decydują wprawdzie o poziomie inwestycji w Słowacji, ale Bratysława (nie bez racji) liczy na stworzenie przez nie korzystnego klimatu dla podejmowania takich decyzji przez kierownictwa korporacji pochodzących z tych krajów.

Nieco bardziej zniuansowana jest polityczna taktyka, stosowana przez rząd słowacki, celem uzyskania stałego dopływu środków z funduszy unijnych. RS posługuje się tutaj znów wypróbowaną metodą utrzymywania bliskich stosunków z niemiecko-francuskim tandemem, korzystając jednocześnie z solidarności z grupą V4, którą łączy wspólne zainteresowanie utrzymaniem dotychczasowej polityki wspierania nowych państw członkowskich przy pomocy Funduszy Strukturalnych, pozwalającej im na ograniczanie wydatków na inwestycje infrastrukturalne i wspieranie rolnictwa. Podejście do tej kwestii znów ma raczej charakter taktyczny niż strategiczny, zmieniając się w zależności od okoliczności negocjacyjnych. Jest jednak mało prawdopodobne, żeby Słowacja stanęła solidarnie po stronie któregoś z państw V4, poza Czechami, jeśli w trakcie trwających obecnie negocjacji perspektywy budżetowej 2021-2027 środki dla niego zostaną uszczuplone, chyba że nie będzie się to wiązało ze stratami, lub będzie można przysługę wymienić na poparcie w innej sprawie.

Dosyć zbliżone instrumentarium stosuje RS, chroniąc swój kolejny interes strategiczny w postaci poszerzania wpływów w UE. Zasadniczym narzędziem jest oczywiście udział w głównym nurcie integracji, przejawiający się przede wszystkim obecnością w strefie euro, dlatego Słowacja nie przyłączyła się do płynącej z Budapesztu i Warszawy krytyki propozycji reformatorskich Macrona zawartych w treści przemówienia wygłoszonego na Sorbonie 26 września 2017 r., wśród których zawar- 
te zostały m.in. postulaty powiększenia wspólnego budżetu opartego na strefie euro i wzmocnionego nowymi podatkami oraz akceptacji dla idei różnych prędkości integracji celem umożliwiania zwiększania jej zakresu przez państwa przodujące bez konieczności włączania pozostałych (Sorbonne, 2017). Słowację stać wprawdzie na opór wobec czołowych państw europejskich, ale jest on zazwyczaj ostrożny i towarzyszą mu gesty pozwalające na utrzymanie zdolności manewrowania i wyjście z konfliktu, celem utrzymania prointegracyjnego kursu. Przykładem tego rodzaju działania jest postępowanie rządu słowackiego w trakcie gwałtownego napływu uchodźców związanego z wojną w Syrii. Delegacja słowacka głosowała przeciwko decyzji Rady z 22 września 2015 r., powiększającej do 66 tys., a docelowo do 120 tys. liczbę kandydatów na azylantów, podlegających rozdysponowaniu zgodnie z systemem kwotowym (Decyzja Rady (UE) 2015/1601, art. 4). Zaraz po głosowaniu premier Fico ogłosił, że Słowacja nie przyjmie przypisanej jej kwoty, decydując się przy tym na wystosowanie wspomnianej już skargi do TSUE. Charakterystyczne jest jednak, że to stanowisko (niedługo po wyborach parlamentarnych) zostało dyskretnie złagodzone. RS nie wycofała się wprawdzie z krytyki systemu rozdziału uchodźców, ale przyjęła symboliczną liczbę 16 osób z Grecji, a następnie jeszcze kolejnych 60 (Šimečka, 2017), zawierając z Austrią porozumienie o umieszczeniu w Gabčíkovie 500 osób z przepełnionego ośrodka w Traiskirchen Jak Słowacja uniknęła, 2017), a do tego w grudniu 2015 r. zaprosiła 149 chrześcijan z Iraku (Łada, 2017, s. 9). To zestawienie posunięć potwierdza tezę Bajdy i Zenderowskiego, że sprzeciw Słowacji nie był tyko wyrazem przedwyborczego koniunkturalizmu Smeru i jego przewodniczącego, ale próbą zażegnania sytuacji przenoszenia kontrowersyjnych spraw do Rady, gdzie do zablokowania propozycji niezbędna jest koalicja co najmniej 4 państw dysponujących 35\% ludności (Bajda, Zenderowski, 2017, s. 38-39). System głosowania ogranicza skuteczność działania związków niewielkich państw, takich jak V4 (ich łączna ludność składa się na 13\% populacji UE), zaś trzeba przypomnieć, że kwestia rozdziału uchodźców została przeniesiona pod wpływem Komisji Europejskiej na forum Rady ds. Wymiaru Sprawiedliwości i Spraw Wewnętrznych z Rady Europejskiej, na której posiedzeniach obowiązuje dążenie do konsensusu. Chodziło zatem o sprzeciw Słowacji wobec pewnej politycznej praktyki ograniczającej jej wpływy w UE, a nie o liczbę przyjętych cudzoziemców, skoro finalnie zgodziła się przyjąc liczbę niewiele niższą od tej, która przewidziana była w kwestionowanej decyzji i wynosiła 802 (Decyzja Rady (UE) 2015/1601). 


\section{Wykorzystanie pozycji zajmowanej przez Słowację w UE na forum Grupy Wyszehradzkiej}

Unikalny status podwójnej przynależności do V4 i głównego nurtu integracji, związanego ze strefą euro, daje RS pewne możliwości w zakresie realizacji wspomnianych wyżej interesów.

Przede wszystkim poprawia on pozycję państwa $\mathrm{w}$ relacji $\mathrm{z}$ jednym z dwóch najważniejszych partnerów o charakterze strategicznym, tj. z Republiką Czeską. W obliczu perspektywy realizacji przynajmniej części wspomnianych postulatów Macrona dotyczących zbudowania twardego jądra UE wokół strefy euro, poprzedni czeski gabinet pod kierownictwem Bohuslava Sobotki postanowił przystąpić do działań dostosowawczych. W ich ramach wystąpił z oryginalną propozycją uzyskania, nieistniejącego do tej pory, statusu członka obserwatora eurogrupy, czyli konferencji ministrów finansów państw strefy euro, na której często zapadają decyzje stanowiące potem kanwę posunięć całej UE (Šafaříková, 2017). Posunięcie to miałoby stanowić alternatywę wobec odejścia od korony, czemu przeciwna jest znakomita większość czeskich wyborców. Nie wiadomo wprawdzie, czy obecny rząd premiera Andreja Babiša będzie kontynuował tę inicjatywę, ale zmienne i niejednoznaczne podejście do strefy euro jego oraz czołowych członków jego partii pozwala sądzić, że pomysł może być podtrzymywany. Aby go zrealizować, Pradze będzie konieczne wsparcie Bratysławy, która do tej pory pełniła wobec niej rolę informatora o treści obrad. W zamian strona słowacka może otrzymać choćby wsparcie dla swojej koncepcji wspólnego rynku energetycznego, zapewniając sobie dalsze zyski z opłat przesyłowych.

Pozycja Słowacji umożliwia jej także rozwiązywanie spraw bieżących w imieniu V4, skutkiem czego może podnosić swój status w Grupie, zwłaszcza w obliczu zmiany położenia Polski, wchodzącej w otwarte konflikty z Komisją Europejską oraz Francją i Niemcami. Nie zapewni to RS oczywiście przywództwa w Grupie, o które z resztą nie zabiega, ale jej pośrednictwo może być na tyle istotne, żeby zapewnić jej pewną specjalizację w V4 i możliwość wymiany usług na wsparcie w realizowaniu jej interesów. Jedna z takich spraw dotyczyła rzekomych podwójnych standardów żywności sprzedawanej przez dużych producentów w starych i nowych państwach UE. To właśnie Słowacja wprowadziła ten temat pod obrady szczytu państw V4 w marcu 2017 roku po przeprowadzeniu laboratoryjnych testów 22 produktów, wykazujących różnice w ich składzie, sprawiając, że szybko trafił on pod obrady Rady ds. rolnictwa i pocią- 
gając za sobą pozostałe kraje Grupy, mimo początkowego sceptycyzmu Polski, której badania nie potwierdziły rażących uchybień w zakresie składu produktów (Sprawa podwójnych standardów, 2017). Bratysława dowiodła tym samym swojej sprawności i siły przebicia w Unii, pokazując, że jest w stanie szybko nagłaśniać sprawy i przekonywać unijne gremia do zajęcia się nimi oraz wpływać jednocześnie na agendę V4. Budapeszt natychmiast zajął miejsce głównego sojusznika Bratysławy. Solidarność okazały też Czechy, gdzie już w 2015 roku przeprowadzono podobne badania, nie potrafiąc jednak nadać sprawie wystarczającej rangi na forum UE (Livingstone, Marks, 2016). Rozgrywanie przypadków tego typu przynosi Słowacji kapitał polityczny w kontaktach z czołowymi państwami Unii, przedstawiając ją jako reprezentanta państw członkowskich o najkrótszym stażu i udowadniając im tym samym swoją skuteczność, co wpływa na zwiększenie jej wagi politycznej.

Omówiona sprawa miała dla Węgier i Polski charakter symboliczny. Forsują one bowiem politykę opartą na tworzeniu wyraźnej tożsamości środkowoeuropejskiej, domagającej się uznania swojej równorzędności, co na użytek polityki wewnętrznej jest interpretowane jako obrona godności narodowej i odrzucanie kompleksów. Słowackie władze wyraźnie jednak dystansują się od udziału w tak widzianej polityce, o co pieczołowicie dbają przedstawiciele rządu. Nieprzypadkowe były wypowiedzi Ficy w rodzaju określenia Słowacji mianem pro-europejskiej wyspy w regionie po zwycięstwie wyborczym partii ANO w Czechach (Slovakia a pro-European, 2017), czy reakcji ministra Lajčáka na projekt „,trójmorza”, którym RS ma być zainteresowana tylko wtedy, jeśli będzie „częścią europejskich działań”, a nie alternatywą wobec UE (Šimečka, 2017).

Słowacja wyraźnie liczy na obsadzenie w roli pośrednika między odradzającym się francusko-niemieckim tandemem a V4. Pozycja ta może zapewnić jej pewne przywileje, zwłaszcza jeśli kraje te zdecydują się na przyjęcie bardziej koncyliacyjnego podejścia do Polski i Węgier oraz przystąpią do stabilizowania UE po „brexicie”. Sygnałem tego jest odmienne potraktowanie Słowacji przez Komisję Europejską, która nie zdecydowała się na uruchomienie wobec niej procedury dyscyplinującej w oparciu o artykuł 258 Traktatu o funkcjonowaniu Unii Europejskiej, mimo że zainicjowano ją wobec pozostałych członków Grupy, w tym Czech, których władze zdecydowały się na przyjęcie 12 uchodźców (Prończuk, 2017).

Z tego względu dla Słowacji nie jest do końca korzystna decyzja unijnego szczytu w Bratysławie z czerwca 2018 roku. Ustalono tam, że relokacja będzie się odbywała na zasadzie dobrowolności, zaś refor- 
ma systemu dublińskiego będzie zatwierdzana na zasadzie konsensusu. Uwzględnione więc zostały opinie państw V4, które odtąd mogą z powodzeniem zrezygnować z przyjmowania imigrantów, nie narażając się na ponowne uruchomienie wspomnianej procedury (Liderzy $U E$ ). Poza tym zwyciężyła, lansowana przez Bratysławę, idea rozstrzygania o kwestiach migracyjnych w oparciu o zasadę jednomyślności. Poprawia to jednak sytuację krajów V4, nie pozwalając Słowacji wyraźnie się wyróżnić i sprawiając, że we wspomnianej kwestii nie będzie już potrzebny pośrednik, który mógłby być wynagrodzony w trakcie negocjowania perspektywy budżetowej 2021-2027.

\section{Wnioski}

Sytuacja zewnętrzna Słowacji umożliwia temu krajowi prowadzenie aktywnej polityki europejskiej. Jej kapitał polityczny opiera się na dobrych stosunkach z Francją i Niemcami, cementowanych udziałem w strefie euro, równie dobrymi relacjami z partnerami z V4, stabilnymi stosunkami z Rosją oraz udziałem w NATO, praktykowanym jednak bez ostentacyjnej polityki proamerykańskiej, co w dobie prezydentury Donalda Trumpa, usuwa potencjalne przyczyny napięć ze wspomnianymi państwami stanowiącymi trzon Unii Europejskiej. Potencjał polityczny związany z tą sytuacją nie jest jednak wykorzystywany w pełni. Trudno bowiem w polityce tego państwa znaleźć poważniejsze własne idee, dotyczące sposobu rozwiązywania problemów, w które obfitują relacje między państwami Unii. Bratysławska dyplomacja ogranicza się zazwyczaj do odnoszenia się do pomysłów innych aktorów, popierając najczęściej rozwiązania proponowane przez Niemcy i Francję. Polityka regionalna Słowacji opiera się zatem bardziej na taktycznym lawirowaniu, niż poszukiwaniu wspólnych strategii z sąsiadami. Trudno wskazać na istotniejsze przykłady poszukiwania przez RS pól zbliżenia między tandemem polsko-węgierskim a francusko-niemieckim, chociaż działania w tym kierunku byłyby możliwe i niewątpliwie przyniosłyby tamtejszej dyplomacji atuty. W miejsce ambitnych projektów tego typu, Słowacja stara się uzyskiwać doraźne korzyści, przyjmując linię przyjazną partnerom z V4, ale w momentach kluczowych akceptując stanowiska silniejszych państw zachodnich i usiłując odnosić korzyści płynące z wizerunku najbardziej prounijnego państwa Europy Środkowej. Działania te łączą zatem podejście multilateralne, w odniesieniu do Unii Europejskiej, z indywi- 
dualnym w zakresie polityki regionalnej. Cechą dominującą słowackiej polityki jest wysoki poziom jej adaptowalności do zastanych warunków. Dowodzi tego przede wszystkim sprawa Gazociągu Północnego, który po okresie kontestacji zaczął być traktowany przez słowacki gabinet jako fakt dokonany, który wymaga już dostosowania się poprzez próby ratowania pozycji tranzytowej w handlu gazem. Trzeba zauważyć, że nie jest to polityka pozbawiona skuteczności. Słowacji udaje się być wewnątrz V4, bez tracenia dobrych relacji z czołowymi państwami UE, a przez to unikać zarówno sankcji ze strony Komisji Europejskiej, jak i regionalnego ostracyzmu. Daje to krajowi dogodną pozycję do prowadzenia negocjacji związanych z perspektywą finansową 2021-2027. Warunkiem kontynuowania tego kursu jest utrzymanie się poparcia społecznego dla silnej integracji, warunkującego dostęp do władzy sił reprezentujących postawy proeuropejskie. Obecne tendencje w polityce wewnętrznej nie gwarantują jego spełnienia.

\section{Bibliografia}

At a glance, http://www.eastring.eu/page.php?page=about, eastring.eu, 9.09.2018.

Bajda P. (2010), Polityka zagraniczna Stowacji, w: Współczesna Stowacja. Sytuacja wewnętrzna i pozycja międzynarodowa, red. E. Pałka, Oficyna Wydawnicza Arboretum, Wrocław.

Bajda P., Zenderowski R. (2017), Europejska polityka Stowacji, „ETE Working Paper", t. 3, nr 3 .

Bilč́k V., Euroscepticism and European Parliament elections, w: Slovakia, red., V. Bilčík, A. Duleba, http://www.eu-28watch.org/?q=node/1221, 1.09.2018.

Bilč́́k V., Groszkowski J. (2016), Polska i Stowacja w Unii Europejskiej, w: Wspótczesne stosunki polsko-słowackie, red. M. Gniazdowski, P. Samerek, T. Strážay, Research Center of the Slovak Foreign Policy Association, Ambasada Rzeczypospolitej Polskiej w Bratysławie, Bratysława.

Czeski minister: Nie odchodzimy od stanowiska V4 ws. pracowników delegowanych, 15.09.2017, gazetaprawna.pl, http://www.gazetaprawna.pl/artykuly/ 1071267,czechy-grupa-wyszehradzka-pracownicy-delegowani.html, 26.01.2018.

Dąborowski T., Duleba A. (2016), Polsko-stowacka wspótpraca energetyczna, w: Współczesne stosunki polsko-słowackie, red. M. Gniazdowski, P. Samerek, T. Strážay, Research Center of the Slovak Foreign Policy Association, Ambasada Rzeczypospolitej Polskiej w Bratysławie, Bratysława.

Dąborowski T., Groszkowski J., Stowacja: poszukiwanie nowego miejsca na mapie gazowej regionu, 27.05.2015, Ośrodek Studiów Wschodnich, https:// 
www.osw.waw.pl/pl/publikacje/analizy/2015-05-27/slowacja-poszukiwanienowego-miejsca-na-mapie-gazowej-regionu, 9.09.2018.

Decyzja Rady (UE) 2015/1601 z dnia 22 września 2015 r. ustanawiajaca środki tymczasowe w obszarze ochrony międzynarodowej na rzecz Włoch i Grecji, Dz. Urz. UE L 248/80 z 24.09.2015.

Dybczyński A. (2014), Teoria sojuszy międzynarodowych, w: Stosunki międzynarodowe. Wokół zagadnień teoretycznych, red. K. Kącka, Wydawnictwo Naukowe Uniwersytetu Mikołaja Kopernika, Toruń.

Goda S., Groszkowski J. (2016), Polsko-słowacka współpraca w dziedzinie bezpieczeństwa i obrony, w: Współczesne stosunki polsko-słowackie, red. M. Gniazdowski, P. Samerek, T. Strážay, Research Center of the Slovak Foreign Policy Association, Ambasada Rzeczypospolitej Polskiej w Bratysławie, Bratysława.

Groszkowski J., Słowacja: Niepokorny beniaminek $w$ grupie euro, 14.10.2011, Ośrodek Studiów Wschodnich, https://www.osw.waw.pl/pl/publikacje/komentarze-osw/2011-10-14/slowacja-niepokorny-beniaminek-w-grupie-euro, 2.09.2018.

Hechter M., Kanazawa S. (2006), Teoria racjonalnego wyboru a socjologia, w: Wspótczesne teorie socjologiczne, red. A. Jasińska-Kania, L. M. Nijakowski, J. Szacki, M. Ziółkowski, Wydawnictwo Naukowe „Scholar”, Kraków.

Słowacja liczba ludności, https://www.populationof.net/pl/slovakia/, 18.08.2018.

Jak Słowacja uniknęła sporu z Unią o uchodźców? Po cichu przyjęła 16 osób, 29.06.2017, „Dziennik Gazeta Prawna”, http://wiadomosci.dziennik.pl/swiat/ artykuly/553139,slowacja-uchodzcy-wygaszony-spor-z-unia-europejska. html, 10.10.2017.

Joint Statement of the Prime Ministers of the Visegrad Group on the Amendment of Posting of Workers Directive, 11.05.2017, visegradgroup.eu, http://www.visegradgroup.eu/calendar/selected-events-in-2017-170203/joint-statement-of-the, 27.01.2018.

Konstytucja Republiki Słowackiej z dnia 1 września 1992 r., http://biblioteka.sejm. gov.pl/wp-content/uploads/2016/11/Slowacja_pol_010711.pdf.

Kublik A. (2018), Land Rover Discovery tylko ze Słowacji. Prace straci kilkuset Brytyjczyków, 12.06.2018, „Gazeta Wyborcza”, http://wyborcza. pl/7,155287,23526130,land-rover-discovery-bedzie-tylko-ze-slowacji.html, 8.09.2018.

Kuciak J., wstęp red. „Die Welt”, Mafia zadomowiła się na Stowacji. Niedokończony artykuł zamordowanego dziennikarza śledczego Jána Kuciaka, 2.03.2018, „Gazeta Wyborcza”, http://wyborcza.pl/7,75399,23091235,mafia-zadomowila-sie-na-slowacji-niedokonczony-artykul-jana.html, 2.09.2018.

Liderzy UE doszli do porozumienia ws. migracji. Nie będzie obowiazkowych kwot relokacji uchodźców, 29.06.2018, Polsat News, http://www.polsatnews.pl/ wiadomosc/2018-06-29/liderzy-ue-doszli-do-porozumienia-ws-migracji-niebedzie-obowiazkowych-kwot-relokacji-uchodzcow/, 12.09.2018. 
Livingstone E., Marks S., Central Europe resents double EU food standard EU's new guard wants to close East-West divide in food ingredients, 3.11.2016, Politico, https://www.politico.eu/article/a-snack-by-any-other-name-varying-foodstandards-irk-new-eu-countries/, 11.09.2018.

Lizak P. (2011), Proces kształtowania się słowackiego przemysłu motoryzacyjnego jako wyraz konkurencyjności regionu, „Prace Komisji Geografii Przemysłu”, nr 17.

Łada A. (2017), Strategia środka. Słowacka polityka europejska w obliczu zmian na kontynencie, Instytut Spraw Publicznych, Heinrich Boll Stiftung, Warszawa.

Meredith S., Slovakia crisis: A double murder and allegations of Italian mafia links trigger political chaos, 16.03.2018, CNBC, https://www.cnbc. com/2018/03/16/slovakia-crisis-the-italian-mafia-eu-cash-and-a-double-murder.html, 2.09.2018.

Mesík J., „Enfant terrible” of the Eurozone - Why did Slovakia refuse to bail out Greece?, 17.09.2010, Heinrich Böll Stiftung, https://www.boell.de/en/navigation/europe-transatlantic-enfant-terrible-of-the-eurozone-10154.html, 2.09.2018.

Morgenthau H. J. (2010), Polityka między narodami. Walka o potęgę i pokój, Difin, Warszawa.

Nič M., Slobodník M., Šimečka M. (2014), Slovakia in the EU: An Unexpected Success Story?, Deutsche Gesellschaft für Auswärtige Politik e.V.

Palata L., Słowacja - najbardziej prorosyjskie państwo Unii Europejskiej. Za dobra cenę gazu Fico nie będzie narażać się Putinowi, 2.06.2014, „Gazeta Wyborcza", http://wyborcza.pl/1,76842,16075127,Slowacja syjskie_panstwo_Unii_Europejskiej_html, 4.09.2018.

Słowacja: szanujemy decyzje Trybunatu. Wegry: jest oburzajaca, 6.09.2017, TVN.24, https://www.tvn24.pl/wiadomosci-ze-swiata,2/premier-slowacji-szanujemydecyzje-trybunalu-w-sprawie-relokacji,770470.html, 1.09.2019.

Prieskum: Väčšina Slovákov podporuje členstvo krajiny v EÚ a NATO, dokonca aj voliči Kotlebu, 30.06.2017, https://slovensko.hnonline.sk/988620-prieskum-vacsina-slovakov-podporuje-clenstvo-krajiny-v-eu-a-nato-dokonca-aj-vol ici-kotlebu, 4.09.2018.

Pronińska K. (2013), Wpływ wspótpracy energetycznej krajów Europy Środkowej na regionalne bezpieczeństwo energetyczne i politykę energetyczna UE, Centrum Europejskie Natolin, Warszawa.

Prończuk M., Polskę, Czechy i Węry czeka proces w Trybunale Sprawiedliwości UE za nieprzyjęcie uchodźców. Możliwe kary finansowe, 29.07.2017, Oko.press, https:// oko.press/polska-czechy-wegry-o-krok-procesu-trybunale-sprawiedliwosci-uenieprzyjecie-uchodzcow-groza-nam-sankcje-finansowe/, 11.09.2018.

Rozwadowska A., Jest porozumienie Macrona, Czech i Stowacji w sprawie pracowników delegowanych. Rumunia usiądzie do rozmów, 24.08.2017, „Gazeta Wyborcza", http://wyborcza.pl/7,155287,22273316,jest-porozumienie-macrona-czech-i-slowacji-w-sprawie-pracownikow.html, 23.01.2018. 
Ručinská S. (2010), Polityka gospodarcza Słowacji, w: Współczesna Słowacja. Sytuacja wewnętrzna i pozycja międzynarodowa, red. E. Pałka, Oficyna Wydawnicza Arboretum, Wrocław.

Šafaříková K., Sobotka chystá nečekaný tah: Česká vláda se plánuje více připoutat k eurozóně, 20.08.2017, „Hospodářské noviny”, https://domaci.ihned.cz/ c1-65851440-sobotka-chysta-necekany-tah-ceska-vlada-se-planuje-vicepripoutat-k-eurozone, 9.09.2018.

Šimečka M. M., Słowacja ucieka przed Polską. Premier Fico porzuca Orbana i Kaczyńskiego i łapie się Zachodu, 12.08.2017, Oko.press, https://oko.press/nawet-slowacja-ucieka-polska-premier-fico-porzuca-orbana-kaczynskiego-lapiesie-zachodu/, 11.09.2018.

Slovakia a pro-European island in its region, PM says, 23.10.2017, Reuters, https:// www.reuters.com/article/us-slovakia-europe/slovakia-a-pro-european-islandin-its-region-pm-says-idUSKBN1CS1M3, 11.09.2018.

Slovakia and the European Union. A single-country study of Slovakia's position in the EU (2010), Country Report, Series III (CORE-series), European Policy Studies, Universiteit van Amsterdam, Amsterdam.

Slovakia joins PESCO initiative, 13.11.2017, „SME”, https://spectator.sme. sk/c/20695566/slovakia-joins-pesco-initiative.html, 4.09.2018.

Slovakia supports US President Trump's opinion on North Stream 2, 1.07.2017, „, The Slovak Spectator", https://spectator.sme.sk/c/20869229/slovakia-supportsus-president-trumps-opinion-on-north-stream-2.html, 11.09.2018.

Slovakia, http://www.parties-and-elections.eu/slovakia.html, 3.09.2018.

Stowacja: F-16 lub Gripeny zastapia MiGi-29, 2.02.2018, defence24.pl, https://www. defence24.pl/slowacja-f-16-lub-gripeny-zastapia-migi-29, 18.08.2018.

Sorbonne speech of Emmanuel Macron, 22.10.2017, http://international.blogs.ouest-france.fr/archive/2017/09/29/macron-sorbonne-verbatim-europe-18583. html, 28.01.2018.

Sprawa podwójnych standardów $w$ produkcji żywności trafi do Rady UE, 2.03.2017, „Dziennik Gazeta Prawna”, http://biznes.gazetaprawna.pl/artykuly/1024176,podwojne-standardy-w-produkcji-zywnosci-ue.html, 11.09.2018.

Standard Eurobarometer 89 (2018), ec.europa.eu/commfrontoffice/publicopinion/index.cfm/ResultDoc/download/.../83136, 2.09.2018.

Standardowy Eurobarometr 80. Opinia publiczna w Unii Europejskiej (2013), http:// ec.europa.eu/commfrontoffice/publicopinion/archives/eb/eb80/eb80_pl_pl_ nat.pdf, 1.09.2018.

Štatút Ministerstva zahraničných vecí a európskych záležitostí Slovenskej republiky, č. 82/2016, Čl. 3,4, https:/www.mzv.sk/documents/10182/2616229/\%C5\%A0tat $\% \mathrm{C} 3 \%$ BAt+Ministerstva+zahrani $\% \mathrm{C} 4 \% 8 \mathrm{Dn} \% \mathrm{C} 3 \% \mathrm{BDch}+\mathrm{vec} \% \mathrm{C} 3 \% \mathrm{~A}$ $\mathrm{D}+\mathrm{a}+\mathrm{eur} \% \mathrm{C} 3 \% \mathrm{~B} 3$ pskych $+\mathrm{z} \% \mathrm{C} 3 \% \mathrm{~A} 11 \mathrm{e} \% \mathrm{C} 5 \% \mathrm{BEitost} \% \mathrm{C} 3 \% \mathrm{AD}+$ Slovenskej+republiky/52418f14-1455-48c7-8a93-bcfbd6667fd4, 18.08.2018. 
Szafrańska M., Budowa interkonektora gazowego Polska-Słowacja. Ponad $100 \mathrm{mln}$ euro $z$ Unii, 17.02.2017, money.pl, https:/www.money.pl/gospodarka/ unia-europejska/wiadomosci/artykul/interkonektor-gazowy-polska-slowacja,231,0,2265063.html, 13.11.2017.

Úspešné slovensko v bezpečnom svete. Stratégia MZV SR, https://www.mzv.sk/documents/10182/621898/Strategia+MZV+definit+260208.pdf, 15.03.2020.

Ústava Slovenskej republiky $\check{C l}$. $86 \quad$ e, https://www.mzv.sk/documents/10182/2616229/\%C5\%A0tat\%C3\%BAt+Ministerstva+zahrani\%C4\%8 Dn $\%$ C3\%BDch+vec\%C3\%AD+a+eur\%C3\%B3pskych+z\%C3\%A 11 e $\% \mathrm{C}$ 5\%BEitost $\%$ C3\%AD+Slovenskej+republiky/52418f14-1455-48c7-8a93-bcfbd6667fd4, 18.08.2017.

Warunki życia i pracy w krajach Europejskiego Obszaru Gospodarczego - Stowacja, Ministerstwo Rodziny, Pracy i Polityki Spolecznej, Departament Rynku Pra$c y$, EURES, https://eures.praca.gov.pl/zal/warunki_zycia/slowacja/Slowacja. pdf, 18.08.2018.

\section{European policy of Slovakia as a member of the Visegrád Group}

\section{Summary}

The text summarizes the main objectives and directions of European policy in Slovakia, as well as the interests of the state which are pursued within this framework. The article begins with a review of the most important interests of the Slovak Republic, which are implemented through its foreign policy. Then, the conditions for the implementation of this type of policy and the method of conducting one of its branches, i.e. European policy, are presented. Afterwards, the extent to which the state's position in the EU can be taken advantage of within the Visegrád Group is discussed. The fundamental context of the analysis is provided by the specific political situation of the country, which is the only member of both the Visegrád Group and the Eurozone. The main goal of the analysis is to show the ways and scale of using this position to pursue one's own interests. Slovakia is shown to be a country whose foreign policy is currently based on strong ties with Germany and France, providing it with access to EU funds, Western investments and energy security.

Key words: Slovakia, foreign policy, Visegrád Group, European Union 